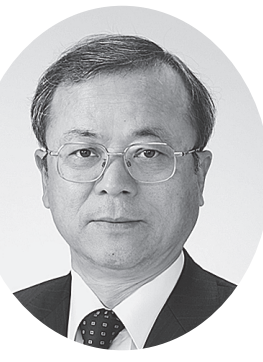

吉田 英雄 ${ }^{*}$

Journal of The Japan Institute of Light Metals, Vol. 65, No. 9 (2015), 432-440

(C) 2015 The Japan Institute of Light Metals

\title{
Development of aluminum alloys for aircraft in Japan: From Zero Fighter to Boeing 777
}

\author{
Hideo YOSHIDA*
}

Keywords: aircraft, aluminum alloy, Extra Super Duralumin, Zero Fighter, Boeing 767

\section{1.はじめに}

日本における航空機産業とアルミニウムの関わりについ て，材料開発の観点から戦前，戦後の歴史（20世紀）をま とめる。戦前, どのようにして超々ジュラルミンのような優 れた材料ができ，零戦に採用されたのかをジュラルミン，超 ジュラルミンに遡って明らかにする。さらに日本における戦 後の民間航空機の開発，YS-11 から B777に至るまでの航空 機の歴史とそれに関わる日本におけるアルミニウム合金の研 究開発についてまとめる。

\section{2. 戦前の航空機産業とアルミニウム ${ }^{1) \sim 5}$}

2.1 ジュラルミン

2. 1.1 ジュラルミンとの出会い

日本のアルミニウム産業が航空機と関わるようになった のは，1916年ロンドン駐在の海軍監督官が墜落したツェッ ペリン飛行船から骨材（図1）を入手し, 海軍が住友伸銅 所に調査依頼したところから始まる。これを入手した伸銅 所は, その分析結果や英国金属学会誌の文献をもとに工場 における試作研究を開始した。1919年工場試作が完了し, 「住友軽銀」と命名された。ジュラルミンは1906年ドイッの ウイルム（ヴィルム, Wilm）によって $\mathrm{Al}-\mathrm{Cu}-\mathrm{Mg}$ 合金で時 効硬化現象が発見され，これをデュレナ・メタルヴェルケ社 によって製品化された合金で，組成は $\mathrm{Al}-4.2 \% \mathrm{Cu}-0.5 \% \mathrm{Mg}$ $0.6 \% \mathrm{Mn}$ である。この合金は従来の合金よりも強度が高いた めに，早速，飛行船（図2）の骨組みに採用された ${ }^{6), 7) 。 ト ゙ ~}$ イツのツェッペリン飛行船は第一次世界大戦で活躍し, ロン ドンなどの空襲で爆弾投下し，ロンドン市民を恐怖に陥れ た。その後，ドイツのユンカース社は，1917年に単発複葉

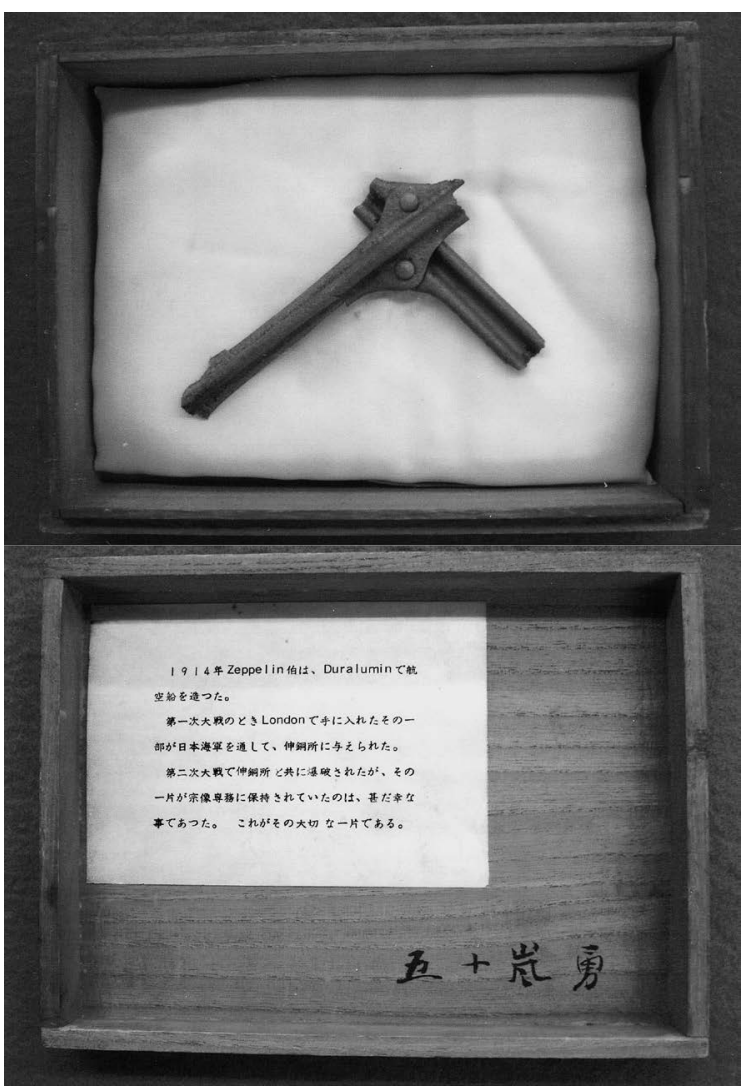

図 1 UACJ 技術開発研究所に保管されているツェッペ リン飛行船の骨材

攻撃機J4にジュラルミンを使用し，1919年には波板状ジュ ラルミンを使用した全金属製旅客機F.13を開発している。

\footnotetext{
*株式会社UACJ 技術開発研究所（ T455-8670 愛知県名古屋市港区千年3-1-12） Research \& Development Division, UACJ Corporation (3-112, Chitose, Minato-ku, Nagoya-shi, Aichi 455-8670) E-mail: yoshida-hideo@uacj.co.jp 受付日：平成27年6月28日受理日：平成27年7月 16 日
} 


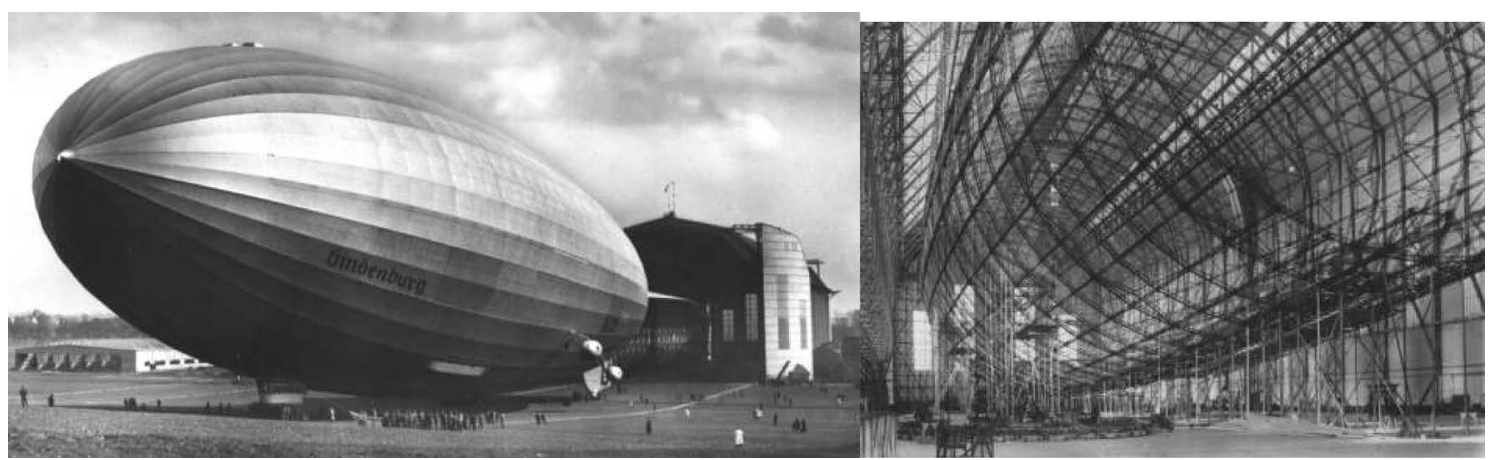

図2 ツェッペリン飛行船LZ129（ヒンデンブルグ号）の外観 ${ }^{6 ）}$ とその骨格

2.1.2 日本におけるジュラルミンの飛行船, 航空機への 適用

第一次世界大戦後は各国で飛行船の製造が行われ，日本 では海軍が英国ビッカース社に発注したSS 型軟式飛行船の 第2〜4船を横須賀海軍工廠において国産化することになっ た。SS とはSubmarine Scoutの頭文字を採ったもので，対潜 水艦哨戒用であることを意味する ${ }^{8)}$ 。1921 年，住友伸銅所は 初めてジュラルミンの工業生産を行い, この飛行船の吊り 船やそのほかの構造材料として板管棒計 1 トン余りを受注し た。1922年 4 月, 中島式ブレゲー型飛行機B-6型（図3）の

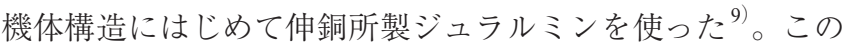
飛行機は「軽銀」と命名された。1925年には川崎航空機(株 から陸軍のドルニ工試作重爆撃機（陸軍制式は八七式重爆撃 機）の外板等を受注した。本機は胴体，翼とも木製骨格に羽 布張りの複葉単発機で，機体前部のエンジン周辺だけ金属製 となっていた。ジュラルミンの本格的採用は1930年以降の 全金属製の機体となってからである。九二式および九三式重 爆撃機，九三式双軽爆撃機は，ユンカース社の機体をベース に設計されたためにユンカース式の波板構造の全金属機で波 板外板によって覆われていた。

ジュラルミン製造にあたっては，海軍が飛行艇を建造す るために英国から招聘した技術者のペーガン氏の指導と第 一次世界大戦で戦勝国となった日本がドイツから賠償の一 環として，ジュラルミンの製造技術をデュレナ社から学んた ことが大きい。さらに, アルコア社（1928年以降はアルコ ア社から分離したアルキャン社に変わった）は地金販路の 拡大のために住友と提携し，住友はアルコア社の協力のも とに 1928 年大阪桜島に溶解炬とアルミニウム板専用の圧延 工場を建設することとなった。板だけでなく，管，棒，線 材や押出形材のための押出機, プロペラ翅用の鍛造機も導 入され，ジュラルミン製造技術も確立していった。ジュラ ルミンは米国では17S（2017）と呼称された。17S-T4は引張 強さ $430 \mathrm{MPa}\left(44 \mathrm{~kg} / \mathrm{mm}^{2}\right)$, 耐力 $270 \mathrm{MPa}\left(28 \mathrm{~kg} / \mathrm{mm}^{2}\right)$, 伸び $22 \%$ を有する合金であった。古河も 1921 年頃, ジュラルミ ンの破片を入手して研究を開始し，1926年，陸軍よりジュ ラルミンの試作命令を受け，石川島造船所にジュラルミン板 $500 \mathrm{~kg}$ を納入した。

\section{2 超ジュラルミン ${ }^{1}$}

2.2.1 米国での超ジュラルミン開発

合金開発ではさらに高強度が求められ，世界中でジュラル ミンを超える超ジュラルミンの研究開発が進行した。当時の 超ジュラルミンはジュラルミンの強度レベルを超える合金は

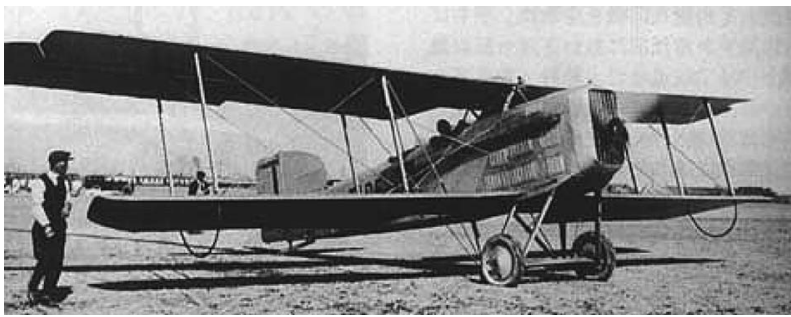

図3 中島式ブレゲー型飛行機,「軽銀」9

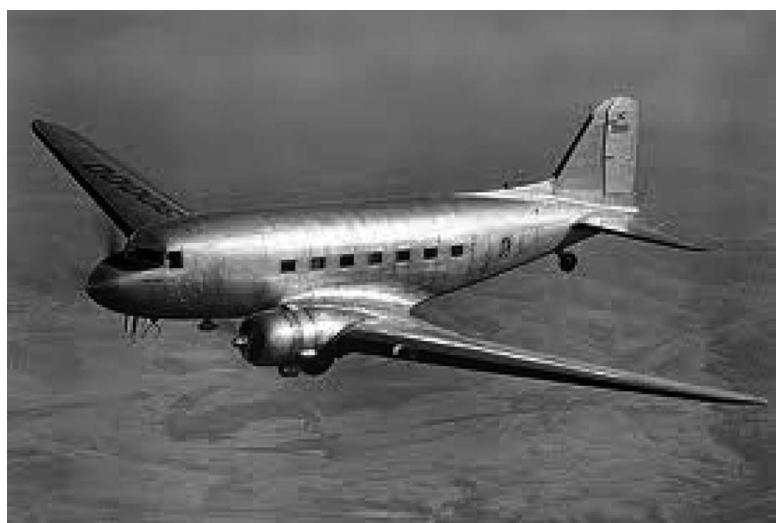

図4 Alclad 24-T3板をスキンに用いたDC-3 $3^{10}$

どれも超ジュラルミンと呼ばれた。超ジュラルミンという 名称を最初に用いたのは，1927年アルコア社のジェフリー スが米国機械学会で高強度合金について報告したのが最初 といわれている。アルコア社はまず，1928年，Si を添加し た $14 \mathrm{~S}(\mathrm{Al}-4.4 \% \mathrm{Cu}-0.4 \% \mathrm{Mg}-0.9 \% \mathrm{Si}-0.8 \% \mathrm{Mn})$ を開発した。 $14 \mathrm{~S}$ は焼入れ焼戻し（T6調質）で引張強さ $480 \mathrm{MPa}(49 \mathrm{~kg} /$ $\left.\mathrm{mm}^{2}\right)$, 耐力 $410 \mathrm{MPa}\left(42 \mathrm{~kg} / \mathrm{mm}^{2}\right)$ が得られたが, 伸びが $13 \%$ と低いので，板材としてょりも鍛造品で多く用いられ た。当時, ケイ素を多く含有した超ジュラルミンを含ケイ 素型超ジュラルミンと称していた。1931年，24S（Cu 4.5\%, $\mathrm{Mg}$ 1.5\%, Mn 0.6\%）が同じくアルコア社によって開発され た。ジュラルミン中の $\mathrm{Mg}$ 量を $1.5 \%$ まで増加させたもの で，含ケイ素型超ジュラルミンが人工時効を必要とするの に対し，24Sは室温時効だけでジュラルミンを超える強度 に達する特徵がある。これを $24 \mathrm{~S}$ 型超ジュラルミンと称し た。現在では超ジュラルミンというと $24 \mathrm{~S}$ を指すことが多 い。24S-T3は, 代表值で引張強さ $480 \mathrm{MPa}\left(49 \mathrm{~kg} / \mathrm{mm}^{2}\right)$, 耐 力 $340 \mathrm{MPa}\left(35 \mathrm{~kg} / \mathrm{mm}^{2}\right)$ で, ジュラルミン $17 \mathrm{~S}$ に比べ耐力が $20 \%$ 高い。T3 調質では圧延材や押出材を焼入れ後矯正ある 
いは残留応力を最小限にするために $1.5 \sim 3 \%$ の引張加工をす ることで強度も向上する。24S-T3 は強度も高いためにすぐ に17S-T4に取って代わった。そして純アルミニウムを皮材 としたクラッド材 Alclad 24S-T3 は旅客機の胴体の材料とし ていまなお使われているが，その最初の飛行機がDC-3 (図4) である ${ }^{10)}$ 。

\subsection{2 日本での超ジュラルミン開発}

日本においても，1931～1932年頃になり飛行機の性能は 向上し全金属製の機体になると，材料の比強度の向上が要求 された。当時の日本では, 住友でも焼戻しを行う含ケイ素型 超ジュラルミンが開発されていたが，この合金は伸びが低く 加工性に問題があることと焼戻し後の耐食性に問題があり, また焼戻しに時間を要して生産性が劣るため焼戻しを必要と しない24Sに代わることとなった。1935年，24S型超ジュラ ルミンはSD，その合わせ板はSDCと称され，SDCの皮材は SA3（Al-1.5\% Mn-0.55\% Mg）合金で, アルコアの 24SCより 高強度の合わせ板となった。住友の超ジュラルミン SD は全 金属製低翼単葉機の九六式艦上戦闘機に採用された。住友が 容易に純度の高い地金を用いた $24 \mathrm{~S}$ 系に踏み切れなかった背 景には，当時，樊土頁岩や明樊石から製錬した国産アルミニ ウム地金には不純物が多い問題もあったようである。

\section{3 超々ジュラルミン, ESD と零戦 ${ }^{2)}$}

\subsection{1 超々ジュラルミンの発明}

海軍から将来戦闘機の性能を飛躍させるには, 同じように 軽く，米国の $24 \mathrm{~S}$ よりもらに強力な引張強さ $590 \mathrm{MPa}(60 \mathrm{~kg} /$ $\left.\mathrm{mm}^{2}\right)$ を有するアルミニウム合金が必要ということになり, 住友に開発が命じられた。住友の方も，SD, SDCが工業化で きた段階であったが，他社が $740 \mathrm{MPa}\left(75 \mathrm{~kg} / \mathrm{mm}^{2}\right)$ 級高強度 合金を華やかに宣伝し始めたため, 上層部からも早く開発 せよとのことで五十嵐勇博士に白羽の矢が立った。開発を 担当した住友の五十嵐博士は，合金開発の最大の問題点は 時期割れ（応力腐食割れ）対策だとの認識で, 1935 年 8 月, 合金探索を開始した。まずは強度と加工性から合金系の予 備検討がなされ，最終的にはドイツのザンダー（Sander）の $\mathrm{S}$ 合金 $(\mathrm{Al}-8 \% \mathrm{Zn}-1.5 \% \mathrm{Mg}-0.5 \% \mathrm{Mn}), \mathrm{D}$ 合金（超ジュラル ミン， $\mathrm{Al}-4 \% \mathrm{Cu}-1.5 \% \mathrm{Mg}-0.5 \% \mathrm{Mn})$ ，そして英国のローゼン ハイン (Rosenhain) の E 合金（ $\mathrm{Al}-20 \% \mathrm{Zn}-2.5 \% \mathrm{Cu}-0.5 \% \mathrm{Mg}-$ $0.5 \% \mathrm{Mn}$, 覀鉛を $20 \%$ まで含みZinc Duralumin として知られて いた）をべースに成分が検討された。最大の懸案事項である 応力腐食割れに対しては，クロムの微量添加が非常に有効で あることが明らかとなり，その結果，新合金の代表組成は $\mathrm{Al}-8 \% \mathrm{Zn}-1.5 \% \mathrm{Mg}-2 \% \mathrm{Cu}-0.5 \% \mathrm{Mn}-0.25 \% \mathrm{Cr}$ となった。この 合金は 1936 年 6 月「鍛錬用強力軽合金」として特許出願され,
1940 年 2 月特許になっている。この合金は, 1936年 5 6月 頃，ベースとなった $\mathrm{E}$ 合金， $\mathrm{S}$ 合金，D合金の頭文字をとっ てESD (Extra-Super-Duralumin), 超々ジュラルミンと命名さ れた。

\subsection{2 超々ジュラルミンの零戦への採用}

1937 年 10 月 6 日, 三菱重工業名古屋航空機製作所の主任 設計技師の堀越二郎は課長からカナまじりの和文タイプで 打たれた一通の書類を受け取った。それは，「十二試艦上戦 闘機計画要求書」であった。「十二試」とは昭和 12 年試作発 令, 艦上戦闘機とは航空母艦上から発着する戦闘機のことで ある。堀越氏は「この要求書は, 当時の航空界の常識ではと ても考えられないことを要求していた。もし，こんな戦闘機 がほんとうに実現するのなら，それはたしかに，世界のレべ ルをはるかに抜く戦闘機になるだろう」と述べている。これ が零戦，零式艦上戦闘機の開発の始まりであった。堀越二郎 氏は, 次期戦闘機の開発に際して, 最大の難関は重量軽減対 策と考え，このため一律であった安全率の見直しや，グラム 単位での重量軽減のために, 「肉落とし」と称して, 強度に 関係のないところをくり抜くことも行われた。さらにどのよ うな材料を選択するかが課題となった。内部構造で最も重要 な主翼の桁について, 前の九六式艦戦のときは 45 キロ超ジュ ラルミン SDH（住友の超ジュラルミンで焼入れ後常温時効 した材料) が開発され，その押出形材が生産されていたので, 翼を薄くし，重量軽減に大いに役立った。十二試艦戦では, 九六式艦戦よりもすばやく上昇でき時速 $500 \mathrm{~km}$ 以上が出せ, しかも航続距離が長く, 空戦に優れた性能などが要求された ため，機体がさらに大きくなり重量増加が避けられなかっ た。九六式艦戦と同じ超ジュラルミンでは，桁用の押出形材 を分厚くしなければならずその結果重量増加につながり，桁 の部分が分厚くなると翼も厚くせざるをえなくなり，いっそ う悪くなると考えられた。もっと高強度の軽い材料はないだ ろうかと堀越氏が探していたところに住友のESDとの出会 いがあった。住友を訪問してその詳細を聞いて，ESDをさ しあたり主翼の桁だけに押出形材を使うとして重量を計算し てみると， $30 \mathrm{~kg}$ は軽くなることがわかり，この新しい金属 の使用を航空本部に願い出た。海軍側はむしろ願い出を喜ん で,この新材料の使用を認めた。零戦とその主翼桁材に適用 された ESD押出形材を図5に示す。

\subsection{3 超々ジュラルミンとアルコア 7075}

1940年 7 月，十二試艦戦は制式機として採用され，その年 が日本紀元 2600 年であったところから, その末尾の零をとっ て,「零式艦上戦闘機」と名づけられた。「ゼロ戦」というの は外国のパイロットから「ゼロ・ファイター (Zero Fighter)」

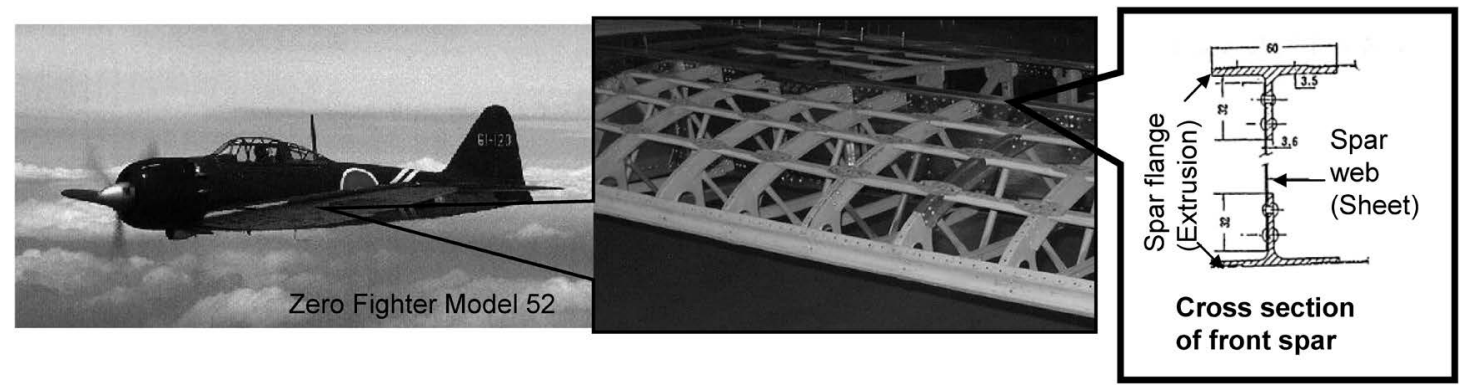

図5 主翼桁に超々ジュラルミン（ESD）押出材を用いた零式艦上戦闘機 
「ジーク（Zeke）」と呼ばれ，外国の評判などから戦後生まれ た零戦の愛称である。太平洋戦争中に, 零戦は各型合計す ると約 10,400機生産された。1942年 6 月のミッドウェー海戦 での敗北が太平洋戦争の転回点となった。同時に行われたア リューシャン作戦で，無人島に不時着したほとんど無傷の零 戦 1 機をアメリカが手に入れた。アメリカは, 真珠湾攻撃以 来，落ちた零戦の切れ端を集めてまでも，空戦性能に優れた 謎の飛行機といわれる零戦の秘密を解き明かそうとしてい た。そして, この完全な零戦に飛行試験を含むあらゆる角度 からの調査を施し，その長所と短所を完全に知ることができ た。米軍を驚かせたのは機体に使われた超々ジュラルミンの 強度の高さであった。それは当時，日本の航空機開発技術に 対して「欧米に数年は遅れている」と考えていたアメリカの 陸海軍や航空機産業関係者の目を覚まさせる一因となった。 その後, 1943年アルコア社は超々ジュラルミンで応力腐食 割れに効果のあるクロムを同様に添加して7075合金を完成 させ，現在でも，7075合金は代表的な航空機用アルミニウ ム合金として用いられている。7075合金の生みの親は超々 ジュラルミンということになる。

\subsection{4 超々ジュラルミンの生产}

1938 年末に, 海軍航空本部から月産 1,364 トンのアルミニ ウム合金生産の要請があり，既定の増産計画の 3 倍もの要求 で，大阪桜島の伸銅所には拡張の余裕がなく，新工場の敷地 が検討され，結局航空機製造の中心地となっている名古屋に 決定した。敷地は，名古屋市港区千年の水田に，博覧会跡地 4 万余坪を加えた約 19 万坪を入手した。この地域は，1937年， 名古屋市長の大岩勇夫氏が名古屋開港 30 周年, 国際都市と しての名古屋をアピールするため名古屋沉太平洋平和博覽会 を開催した会場跡地になっていた。1941年9月，陸海軍大臣 の指揮監督のもと，鋳造，製板，管棒，鍛造を持つ総合的軽 合金専門工場である名古屋軽合金製造所が設置された。この 工場は，当時伸銅所で開発中であった連続鋳造法による大型 鋳塊を用いることを前提としたストリップ方式圧延の製板工 場を目標とした。1944年における桜島の伸銅所製板課第二 工場のアルミニウム合金生産量は 500 600トン/月, 名古屋 軽合金製造所製板工場は最盛期には2,000トン/月（内，スト リップ方式が 1,500 トン/月）であった。なお，管棒生産量は 伸銅所 (桜島), 名古屋でいずれも 300 トン/月であった。形 材生産量は桜島と名古屋でそれぞれ700トン/月であった。名 古屋ではESDの生産が500トン/月であった。な押, 古河電 工や神戸製鋼も軍からジュラルミン，超ジュラルミン，超々 ジュラルミンの製造要請を受け，ESDは住友から特許の実施 権を委譲されて生産された。

\section{3. 戦後の民間航空機の動向 ${ }^{11,}, 12$}

\section{1 YS11 13), 14)}

戦後, GHQにより航空禁止令が布告され, 航空機の研究 開発，製造は禁止されていたため，戦争中，航空機に携わっ ていた研究者や技術者の多くは自動車，鉄道車両やモータサ イクル開発に移っていった。しかしながら, 朝鮮戦争特需で 国内の航空機産業は復活した。1956年，通産省は国産民間 航空機計画を策定し, 航空工業会で国産輸送機開発に関する 構想を発表した。世界の国際路線では大型ジェット機が就 航し，国内路線ではDC-3などのプロペラ機が飛んでいたが,

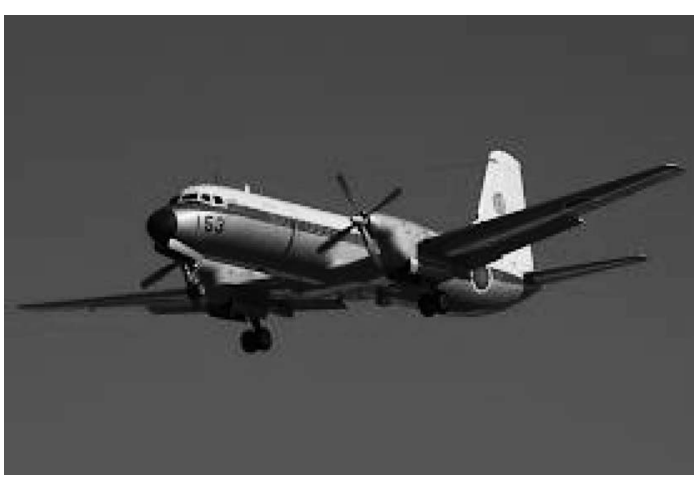

図6 YS11

この旧式プロペラ機の代替として, 日本が開発した国産航空 機を輸出し, 日本の航空機工業を輸出産業のひとつとして育 てたいとの考えであった。

1957 年, 財団法人輸送機設計研究協会（輸研）が東大内 に設立され，乗客 $50 \sim 60$ 人乗りの小型旅客輸送機の設計が 始まった。輸研には戦前の航空業界を支えた技術者が参加, 設計に携わった。試作機を製造するために，1959年官民共 同の特殊法人として日本航空機製造 (NAMC) が設立されて 輸研は解散した。この試作機は双発ターボプロップの旅客機 でYS11 と名づけられた（図6 $)^{15)}$ 。YS は輸送機設計研究協会 の輸送 $(\mathrm{Y})$ と設計 $(\mathrm{S})$ の頭文字に由来する。日本航空機 製造は設計開発, 生産管理, 品質管理, 販売, プロダクトサ ポートを行い, 生産は機体メーカー六社（新三菱重工業，川 崎航空機, 富士重工業, 新明和工業, 日本飛行機, 昭和飛行 機）が分担し, 最終組立は新三菱重工業が行った。飛行試作 機 1 号機は 1962 年 7 月に新三菱小牧工場でロールアウトし, 初飛行は 8 月に行われた。1973年 5 月に最後の機体が送り出 されるまで10年間製造された。1964年に日本の航空局の型 式証明を，1965 年にアメリカ連邦航空局（FAA）の型式証 明を取得した。

量産に着手して，順調に生産が続いていたが，海外での セールスでは非常に苦戦して抒り, 事業収支では悪化してい た。当初，50〜100機の輸出が期待できると見込まれていた が, 日本航空機製造は航空機の製造も販売も初めての経験 で, 航空機の販売のノウハウもないに等しい状態であり, 結 局 12 か国，16社の航空会社に 79 機が輸出されるにとどまっ た。その結果, 日本航空機製造は 360 億円に及ぶ累積赤字と なり，通産省は1971年にYS-11を182機で打ち切ることを決 定した。日本航空機製造は1982年解散し, 残務は三菱重工 業に引き継がれた。な拐，素材のアルミニウム材料は，日本 のアルミニウム材料メーカーも採用に向けて意欲を示した が，YS-11に使用する量のみの生産では，量産効果が出ず， 輸入品より有利な価格で調達できないため, 結局アメリカ製 の材料が採用された ${ }^{14)}$ 。

\section{2 三菱 MU-2, MU-300}

YS11の開発が始まった 1960 年頃から, 三菱は小型ターボ プロッププロペラ機で, 北米の社用・自家用のビジネス向 け（7～9人乗客）に独自の設計を進めた。1963年に試作 1 号 機が初飛行し，1965年，運輸省航空局の型式証明を，11月 にアメリカの連邦航空局（FAA）の型式証明も取得でき, 翌 1966年にMU-2（図7(a) $)^{16)}$ として発売を開始した。しかし 
ながら，アメリカには国内で飛ばす航空機は，その50\%以 上を米国製の部品で作られていなければならないというバイ アメリカン法があり, そのために現地委託して部品を調達し たが，うまくいかず三菱が自らやらねばならなくなった。三 菱が販売を開始した 1967 年, ようやく5機を受注して以降, 安定性の高い飛行機として評判が広がり，年産 40 機から 50 機にまで成長した。ところが，1971年ニクソン・ショック の影響を受け，円は急速に值上がりし，MU-2も採算割れを 起こして赤字が増大した。しかし赤字ながらも販売は好調 だった。1973年秋の中東戦争により世界的なオイルショッ クとなり，燃料費の高騰によってエアラインは軒並み経営不 振となりMU-2の受注が急減した。1987年，新型機MU-300 に販売を集中するため, MU-2の生産を終了した。総生産数 は757機，世界27か国で販売され，世界の小型機の中でもべ ストセラーであった。

MU-2が好調であった1969年, 三菱はMU-2 よりもワンラ ンク上の高級ビジネスジェット機を計画した。市場調査の結 果, 最高速度は約 $800 \mathrm{~km} / \mathrm{h}$, 快適な広いキャビンを備え, 高 い燃焼効率を持った機体を目指して，1976年に開発に着手 し，1978年にMU-300（図7(b) ${ }^{17)}$ として初飛行した。しか しながら，1979年（昭和 54 年），マクドネル・ダグラス社の DC-10の航空機事故後, FAA は審査基準を大幅に厳しくす ることとなり，FAAの型式証明を取得できたのは1981年に 入ってからであった。さらに日本は円高不況で売上は伸び悩 み，一方，アメリカ政府は高金利政策をとったことで不況に 陥り，航空業界も軒並み経営覀化しビジネス機の需要は皆無 となった。三菱は，ビーチクラフト社と提携し，BEECHJET 400 （ビーチジェット400）の名で販売することにしたが利 益をあげられず，1988年，設計を含めた生産過程すべてを ビーチに売り渡す契約に合意し，同年に日本国内での販売も 終了した。MU-300 はその後米国のビーチ社の Hawker 400 お よび米軍の訓練機 T-1A Jayhawk として生産・運用中で，これ までに総計約 800 機が生産されている。

なお，富士重工業も愛称エアロスバルで知られる軽飛行機 FA-200を製造した。1965年（昭和40年）に初飛行し，1986 年（昭和 61 年）に生産終了するまでに，試作機 3 機を含め て299機が製作された。FA-200に続いて，米国のロックウェ ル・インターナショナル社と共同でビジネス用双発プロペラ 機FA-300を開発して1975年初飛行したが，オイルショック の影響により 47 機で生産終了となった。

\subsection{YX計画とボーイング 767}

1966 年，YS-11に続く民間機の研究のため航空審議会に よって「次期民間輸送機のための研究」が始まり，1968年 には「90席前後のターボジェット旅客機」が発案された。

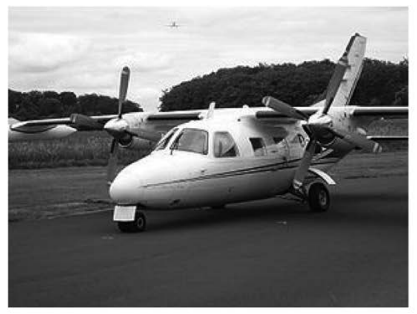

a) MU-2

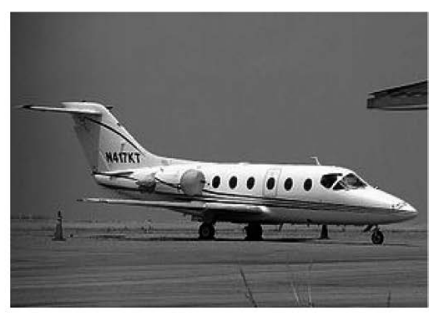

b) $\mathrm{MU}-300$
図7 三菱重工業製ビジネス飛行機MU- ${ }^{16)}$ と MU-300 ${ }^{17}$
日本航空機製造内に「YX開発本部」が設置されて, 市場調 査と基礎設計が行われた。開発費が高騰すると見込まれる中 で，1970年ごろ，外国各社が同クラスの機体の共同開発を 持ちかけてきた。1971年, 共同開発先を見極めるため「航 空機工業海外調査団」がアメリカに派遣された。ボーイング は日本を対等パートナーとして $50 \%$ の分担比率を提示した ため, YX開発専門委員会は，「交渉相手として，当面ボー イングを第一対象とする」と決めて，YX計画は本格的に動 き出した。その後1977年7月の日米交渉において, 分担率 はボーイング $70 \%$ ，アエリタリア $15 \%$ ，日本 $15 \%$ に決定し， 当初の $50 \%$ から大きく後退した。開発の全責任はボーイン グが負い，主導権を持つこととなった。

1978年，ボーイングが7X7の受注を獲得したことから， 民間航空機開発協会とボーイングの間で基本事業契約が締結 され，7X7の開発が開始された。YX/7X7はボーイング 767 となり, 日本では民間航空機開発協会が三菱重工業, 川崎重 工業, 富士重工業に作業を委託し，3社によって分担開発さ れた。開発部位は三菱が後胴パネル, 川崎が前胴・中胴パネ ル，富士が主翼胴体間フェアリングを担当し，ボーイングに 引き渡すこととなった。767は1981年に初飛行, 1982 年7月 に連邦航空局の形式証明を取得して9月に就航した。767全 シリーズの平成 24 年 12 月までの受注数は 1,108 機, そのうち 1,040 機が納入されている。

\subsection{YXX計画とボーイング 777}

1979 年 8 月，新たな国産機「YYS-11の精神を引き継ぐ, 日本独自の計画」として「100席クラスまたはそれよりやや 大型」旅客機の開発計画が始まった。これがYXXである。 日本航空機開発協会 (JADC, 民間輸送機開発協会が新明和 工業と日本飛行機が加盟したことから改組）はボーイングが 参加を打診してきた7J7を共同開発することを決定した。こ の YXX/7J7 の概要は, 座席数は 147 席から 166 席とし, ター ボプロップエンジンより進歩したプロップファンエンジンを 搭載した双発プロペラ機で，開発比率はボーイング $75 \%$ ： 日本 $25 \%$ とするものであった。しかし, ターボファンエン ジンの高性能化によってジェット機の燃費も向上したため, 7J7 の魅力もなくなって, 1987 年にはボーイングの 7J7 計画 は事実上中止となった。

その後, ボーイングは国際分担によって開発費を減らすこ とと，日本の高品質低価格の技術力や日本の開発費に関心を 示して, 747 と 767 の間を埋める 350 席クラスの中型旅客機

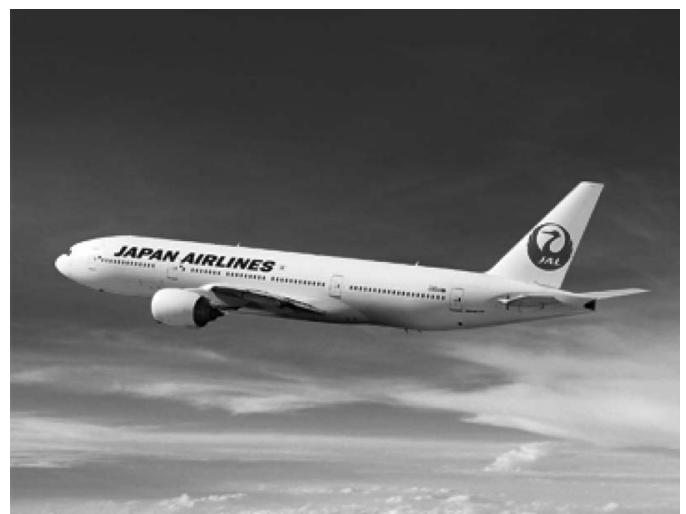

図8 ボーイング $777^{18)}$ 
の共同開発を改めて日本に打診してきた。日本航空機開発協 会は，アメリカの対日感情悪化を恐机る日本政府に配慮す る形で参加を決定した。日本の分担を $21 \%$ （胴体の大部分， 中央翼，主翼胴体間フェアリング，主翼リブなど多数）まで 伸ばすことができたが，やはり最重要な部分からは締め出さ れた。「日本が主体性をもつ」こととしたはずのYXXも，結 局ボーイングの 777 (図 8) ${ }^{18)}$ の共同開発となった。1994年, 777 の 1 号機がロールアウトした。1998年より量産事業への 移管に伴い，JADCの権利義務は民間航空機株式会社 (CAC) に移管された。平成 24 年 12 月末現在の受注数は 1,541 機であ り，そのうち 1,263 機が納入されている。

\subsection{YSX計画}

日本航空宇宙工業会はボーイングが絶対的主導権を握る YXXよりも日本に主体性をもたせた輸送機計画を持つべき だとして，1986年に「民間機調査検討委員会」を設置し， 以下の機体の検討をはじめた。(1) 50 席から 100 席の小型機開 発の検討, (2)YS-11の姿勢を引き継ぎ, 経験を生かせる機体, (3)共同開発に扔いても，マーケティング，商品企画，開発， 生産，販売，サポートに挄いて日本が主体性とメジャーシェ アを保つこと。翌1987年, ターボファンエンジンの双発と することになった。1989年に日本航空機開発協会は, 夕ー ボファン双発・75席輸送機の開発と, 国際共同開発の可能 性の検討をはじめた。1991年には，「小型民間機（YSX）開 発調査」が開始された。1994年4月になると，ボーイングが 突如YSXへの関心を強めたが，1997年ボーイングはマクド ネル・ダグラス MDを吸収合併し，MD-95を「ボーイング 717-200」として継続販売すると発表し，事実上のYSXを放 棄した。2000年，国家産業技術戦略検討会は，当面 YSX開 発の可能性はないとして, YSX放棄を発表した。

この間, 三菱はボンバルディアとの間で小型リージョナル ジェット機の共同開発を次々に進め, 川崎重工業もこのころ 三菱への対抗上，エンブラエルへの接近姿勢を強めていた。 2002 年 8 月末に経済産業省が発表した 30 席から 50 席クラス の小型ジェット機開発案「環境適応型高性能小型航空機」で, YSXまでの企業各社横並びの事業を取りやめ, 積極的な企 業が自己責任で開発を推し進めることとした。この開発が三 菱重工業のMRJに繋がる。

\section{4. 戦後の航空機用アルミニウム合金の研究開発}

戦後，一時期，航空機の研究開発，製造は禁止されていた が, 朝鮮戦争特需で復活し, その後, 日本の航空機メーカー はYX, YXX 計画 $(767,777)$ でボーイング社の機体の分担生 産を通して成長してきた。この間, 戦前から航空機材の生産 を行ってきた住友軽金属, 神戸製鋼, 古河電工の 3 社もまた ボーイングの認定を受け素材の国産化を行って機体メーカー に供給してきた ${ }^{19)}$ 。特に, 現UACJの福井工場は広幅厚板の 航空機材が生産できる最新鋭の製造設備を有している。

\section{1 航空機用材料の開発}

4.1.1 ストリンガ用材料

ボーイングの B 767 機体の製造では，従来，7075押出形材 を用いたストリンガ（縦通し材）の重量を軽減するため, 図 9 に示すように，板材を圧延により長手方向で肉厚を変動さ せ，継手部分のみを厚くしたテーパストリンガを全面的に用 いようとした。しかしながら, 従来の海外製 7075 板材では, テーパ圧延で弱加工された部分は溶体化処理で結晶粒粗大化 が生じて, その後のハット型加工で割れが発生し, 疲労強度 の低下寸る問題が発生した。このため弱加工でも結晶粒粗大 化しない材料の開発が求められた。住友軽金属の馬場, 宇野 らは連続焼鈍炉を用い急速加熱, 急速泠却処理で結晶粒を $50 \mu \mathrm{m}$ 以下に微細化し，その後適正な析出処理により軟化さ せることで，テーパ圧延の弱加工・溶体化処理で結晶粒粗大 化が生じない加工熱処理法を開発し国産化した ${ }^{20)}$ 。三菱重工 業はこの加工熱処理を施した板材をハット型に成形し，ボー イング767,777のストリンガに用いることができた。図9の 767 機の胴体外観から，ハット型に成形されたテーパストリ ンガと湾曲したフレームと外板がリベットで組み合わされて いる様子がわかる ${ }^{19), 21)}$ 。その後，ストリンガのコストダウ ンや耐応力腐食割れの改善のための成分や調質（RRA処理） の検討, 復元処理利用による加工工程の簡略化を三菱重工業 と共同研究した ${ }^{22,23)}$ 。さらに, テーパ圧延での圧延加工度 が大きくなると結晶粒が微細化して耐応力腐食割机性が低下 することが懸念されたため, 結晶粒のアスペクト比（圧延方 向の長さと板厚方向の長さの比）に注目して, アスペクト比 が設計要求を満足する4以上になるような加工熱処理法を開 発した ${ }^{24)}$ 。テーパ圧延後, 溶体化処理前に $343^{\circ} \mathrm{C} て ゙ 2$ 時間の 予加熱を施すことによってすべての加工度で4以上になるこ
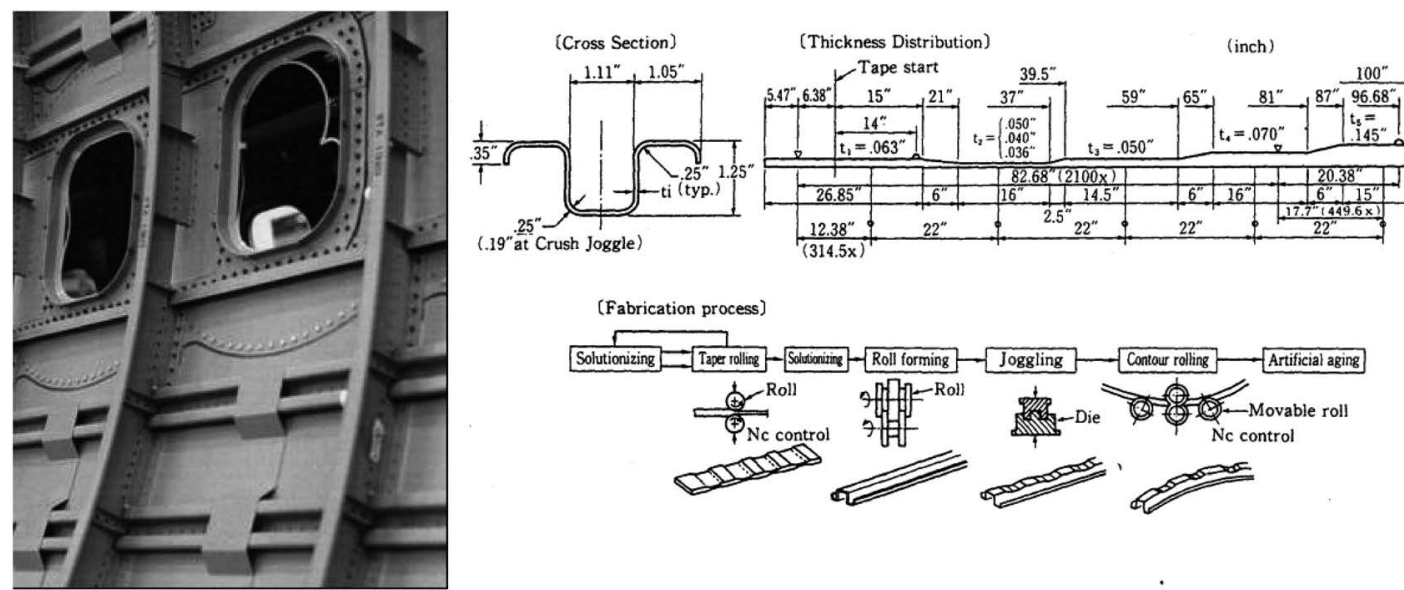

図9 フレーム、テーパストリンガと外材でできたボーイング767胴体とテーパストリンガ材の製造工程 ${ }^{19)}$ 
とが確認され，777のストリンガに採用された ${ }^{22) ~ 24) ~}$

4. 1.2 超塑性材料

住友軽金属は三菱重工業と共同で7475 合金, Al-Li合金超 塑性材開発と超塑性加工法の開発（1983～1988年）の研究 を実施した ${ }^{25)}$,26)。図 10 は工場で試作した7475合金超塑性材 を用いて一体化加工されたドアパネルのモデルである。こ の 7075 合金は, 熱延板に対し適切な析出処理（過時効処理） を施し，その後，冷間圧延と急速加熱処理を行う加工熱処理 法を用いると， $10 \mu \mathrm{m}$ 程度まで結晶粒は微細化する。この材 料を高温で引張変形させると超塑性が得られることから，ド アパネル等に成形された。この超塑性成形法により，図 10 に示すドアパネルでは，従来方法では 45 個のパーツ，400 個 のリベットで加工されたパネルに対して，3個のパーツと 80 個のリベットで組立ができ，コストで $30 \%$ ，重量で $15 \%$ 軽減 されることがわかった ${ }^{25)}$ 。そのほかの実際の超塑性成形事 例に関しては文献27),28）を参照されたい。

$\mathrm{Al}-\mathrm{Li}$ 合金も高温で超塑性を示すことはよく知られてい る。このため 7475 合金で開発した加工プロセスを $\mathrm{Al}-\mathrm{Li}-\mathrm{Cu}-$ $\mathrm{Mg}-\mathrm{Zr}$ 系 8090 合金に適用したところ, 圧延方向では $10^{-3} \mathrm{~s}^{-1}$ オーダで 700\%程度の伸びを示すが，圧延直角方向では $300 \%$ 程度と異方性を示すことが明らかとなった。この異方性をな くすために温間圧延による新たな加工熱処理法を検討した。 その結果，8090合金は異方性が小さく，500 ${ }^{\circ} \mathrm{C}$ 到達後 10 分保

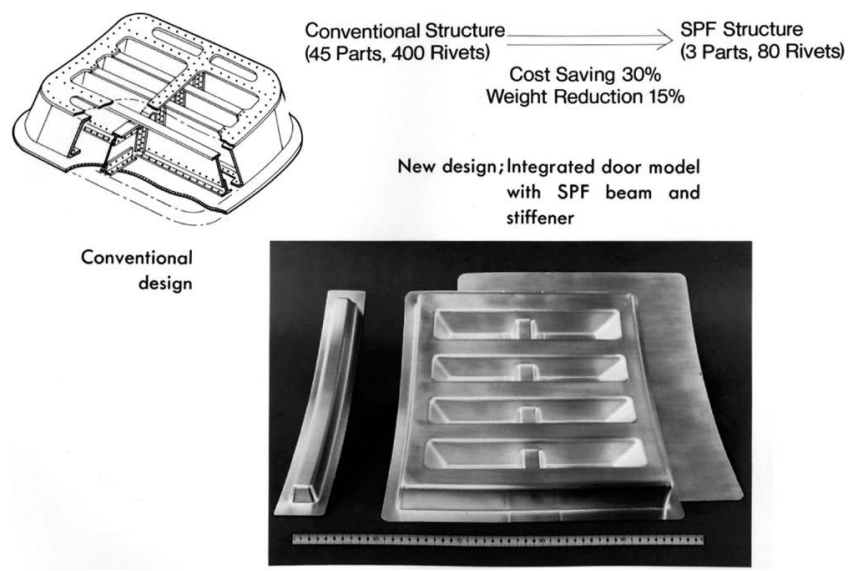

図10 超塑性成形でできたドアパネルのモデルと従来 法で製造したドアパネルの比較 ${ }^{25}$

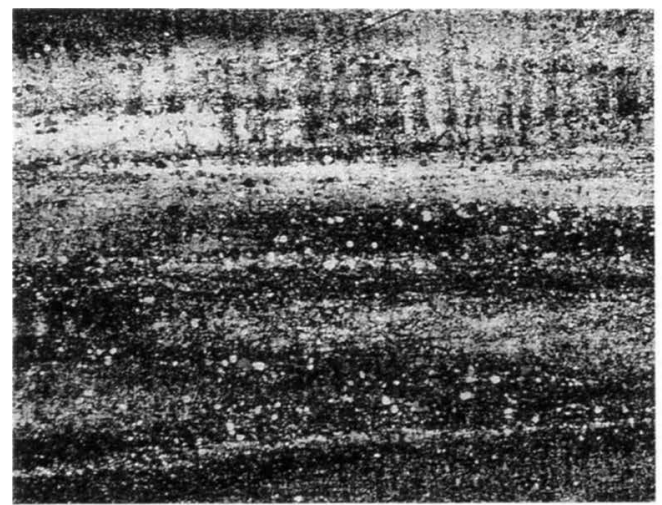

Previous process
持し， $5.6 \times 10^{-3} \mathrm{~s}^{-1}$ で引張試験すると L, LT 方向で $1100 \%$ の伸 びが得られた。8090合金について, 従来工程と温間圧延に よる新工程による伸びの比較を図 11 に, $500^{\circ} \mathrm{C}$ で 5 分間ソル

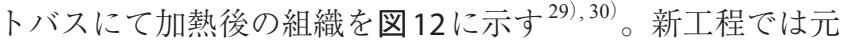
の結晶粒界が消失し, 均一微細な組織の得られることがわか る。さらにこうした加工熱処理法で製造された材料は室温強 度の異方性もなく，室温での伸びも高いことがわかった ${ }^{31 ） 。 ~}$ Al-Li合金の機械的性質の異方性に関して, これを解決する 加工熱処理法を開発することができた。成形法においても, 本開発合金板に対して，変形応力の $40 \%$ 以上の静水圧力（背 面圧力）を負荷することで, 真ひずみ $\varepsilon=1.1$ まではキャビティ の発生を防止できることがわかった ${ }^{32)}$ 。

4. 1.3 ポリッシュドスキン材，鍛造材

一方, 神戸製鋼や古河スカイ（現 UACJ）は, ポリッシュ ドスキンの国産化に取り組んだ。航空機は耐食性向上やきず 防止のために，4〜5年ごとに表面を塗装しているが，塗り 替える際に有機溶剤で剥離するため環境に負荷を与えるこ とや，重量のかさむ塗装が省ければ然費の節約にも寄与で きることから，ボーイング社では外板を無塗装で使用する

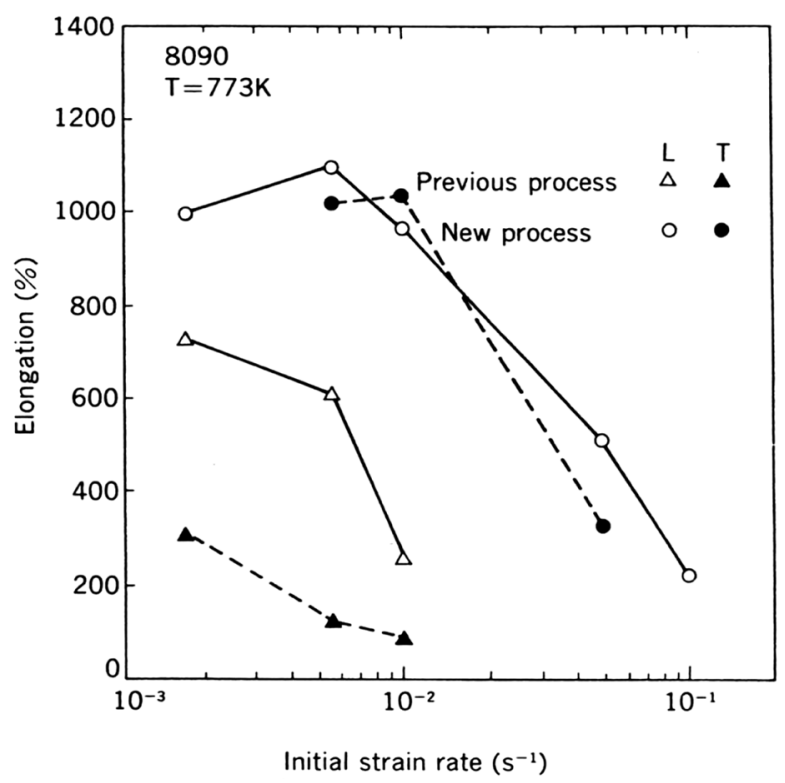

図 $118090 \mathrm{Al}-\mathrm{Li}$ 合金の超塑性特性（従来工程：冷間圧 延, 新工程 : $300^{\circ} \mathrm{C}$ 温間圧延 $)^{29) \sim 31)}$

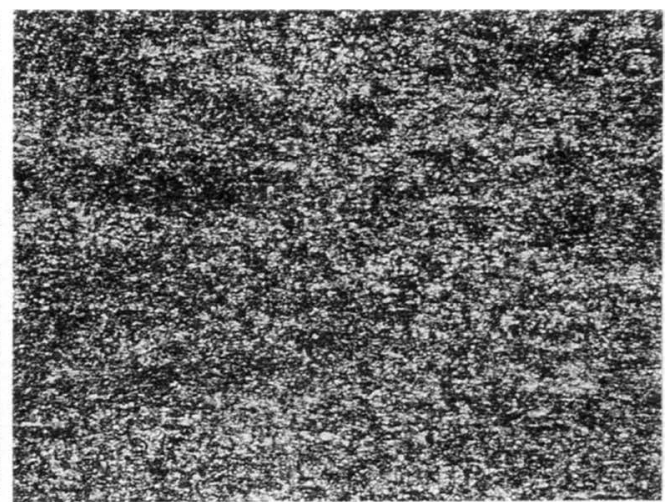

New process
$400 \mu \mathrm{m}$

図12 従来工程と新工程により製造した板材を $500^{\circ} \mathrm{C} ， 5$ 分熱処理（ソルトバス）後のミクロ組織 29 ) 31)。新工程では均一 微細な組織となり，組織の圧延方向での異方性もなくなり，結果として強度や伸びの異方性もなくなった 


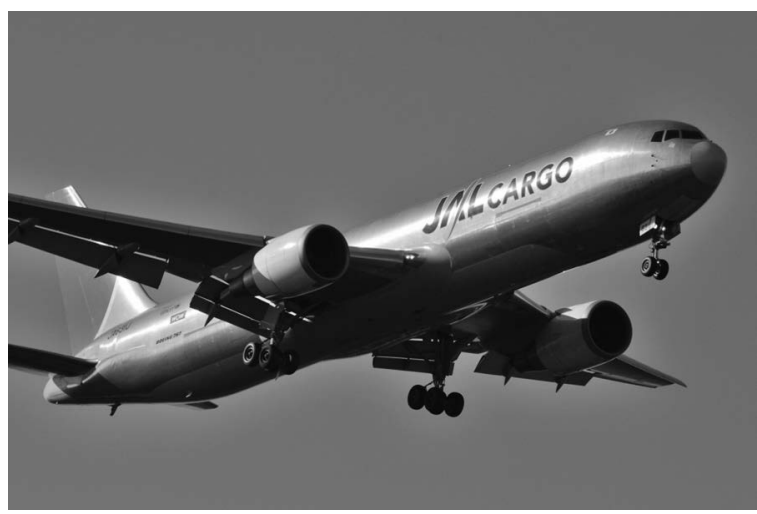

図13 ポリッシュドスキンを用いたボーイング767貨物機 ${ }^{33}$ (写真：Hideo Obayashi 尾林英夫)

ことになった。図13はポリッシュドスキンを採用した航空 機である。当初, Bright Rolled Skin（ロールドスキン）が用 いられたが ${ }^{33)}$, 光沢, ロールマーク, デント, スクラッチ 等, 表面品質が厳しく歩留まりが悪くてコスト的にあわず, 多くの会社が撤退した。その後ボーイング社と MPC（Metal Polishing Co.）と共同でポリッシュドスキンを開発し，アル コア社のみが供給できることとなった。ポリッシュドスキン とは, アルミニウムクラッド材を研磨剤で磨き, 光沢をだし, 表面に形成される自然酸化皮膜で腐食防止をはかる方法であ る。神戸製鋼と古河スカイは，表面きず，色むらがなく，光 沢に優れた表面の評価技術と研磨方法を確立して外板用広幅 クラッド材の国産化に成功した ${ }^{34)}$ 。ただし，このポリッシュ ドスキン材も航空機会社が耐食性を維持するために定期的に 研磨することが必要である。

スキン材では，損傷許容性を高めるために，アルコアが高 純度地金を使用して疲労き裂進展速度を遅くした2524合金 を開発し，B777およびCanada Global Express（GX）の胴体 外板に採用された。三菱重工業も神戸製鋼と共同で2524合 金相当の 2000 系板材を開発し，現行の2024合金に比べて疲 労寿命が約 2 倍に延長でき, その結果として, 最大 $21 \%$ の薄 肉化が可能であることを明らかにした ${ }^{35)}$

そのほか, 鍛造材として, 神戸製鋼は8,000トン精密型鍛 造プレスを導入し, 鍛造方法と残留応力除去技術を確立して

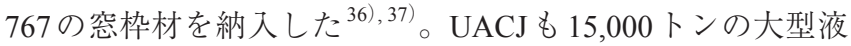
圧熱間鍛造プレスを導入し，2004年より航空機用大型鍛造 品を製造している ${ }^{38)}$ 。

\section{2 航空機用合金および摩擦攪䢁接合の研究}

\subsection{1 高勒性アルミニウム合金の研究}

航空機用アルミニウム合金については，767が日本で分担 生産されるということで, 戦前から航空機用アルミニウム合 金を製造していた住友軽金属，古河電工，神戸製鋼が集まっ て，1980１983 年「高靯性アルミニウム合金開発の研究」 と題して日本航空宇宙工業会の委託研究を始めた ${ }^{39)}$ 。また 同時に, 軽金属学会研究委員会でも，1981年から馬場義雄 博士が部会長を務める材料・物性部会において「高強度・高 勒性アルミニウム合金の諸性質」に関して産学で共同実験を し，高力アルミニウム合金開発の指針を得た ${ }^{40)}$ 。

\subsection{2 $\mathrm{Al}-\mathrm{Li}$ 合金の研究}

Al-Li合金の研究開発では, 最近欧米で復活しつつある が，1980年代に低密度，高強度，高剛性材料として着目さ

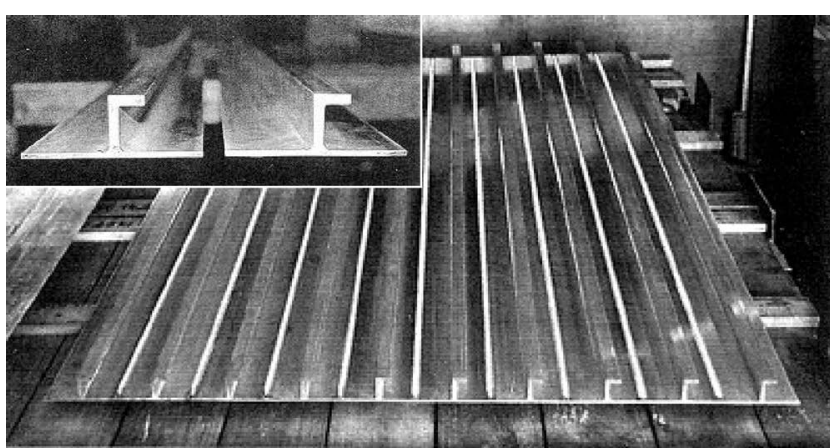

図 14 摩擦攪拌接合法 (FSW) で接合されたパネル（幅 $1531 \mathrm{~mm}$, 長さ $2700 \mathrm{~mm})$ 。左肩の写真はFSWす る前の 7050 押出形材 ${ }^{45)}$

れ，Al-Li合金国際会議が盛んに開催された。日本でも軽金 属学会材料物性部会を中心に 1984 年から 5 年間, 産学共同で 勒性の向上のための基礎的知見を得ることを目的として活動 してきた。その成果は部会報告書「 $\mathrm{Al}-\mathrm{Li}$ 合金」に集約され ている ${ }^{41)}$ 。さらにJRCMの「アルミニウム系新材料の高機能 化に関する調査部会」の構想のもと，(株アリシウムを設立し て1989年から共同研究を開始した ${ }^{42), 43)}$ 。一応予定された範 囲の研究は終了したが，勒性で問題があり，価格が高いこと などがあって，実用化には至らなかった ${ }^{41)}$ 。最近の第三世 代の Al-Li合金は, 8090, 2090, 2091 といった第二世代の AlLi 合金と比較して, Li添加量を $2 \%$ 以下にして, 若干密度を 犠牲にして勒性を向上させているのが特徵である ${ }^{44)}$

4.2.3 摩擦攪拌接合の利用

航空宇宙分野では，FSWはまず再利用しないロケット燃 料タンクに採用された。続いて航空機への適用を目的とした 多数のプロジェクトが立ち上がり, 継手の強度や耐食性など のデータが蓄積されて来た。航空機に用いられる高強度の 2000 系および銅を含む7 000 系合金は，溶接割れ感受性が高 いことから溶融溶接が困難であり，機体はリベット接合によ るスキン/ストリンガ構造が主であった。最近では接合個所 を減らすため, 厚板から切削加工によりリブ付き部材を削り 出すインテグラル構造が翼に用いられているが, 厚板からか なりの量の切削屑を生じる加工であり改善が望まれていた。

住友軽金属と三菱重工業は「摩擦攪拌接合を用いたアル ミ合金製大型押出部材の航空機適用化研究」を行い, 代表 的な航空機部材である2024，7475および7050合金につい て，FSWによる大型押出部材の航空機への適用の可能性 を調査した ${ }^{45}$ ）。継手効率（継手の引張強さ/母材の引張強 さ）はいずれの合金も継手効率 $80 \%$ 以上をほぼ満足してい たが, 応力腐食割れや焼入れ後の曲がり等を考慮して, 溶 体化 $\rightarrow \mathrm{FSW} \rightarrow$ 時効の製造プロセスが有効であることを明ら かにした。図14はFSWにより製造した全幅 $1531 \mathrm{~mm}$ ，長さ $2700 \mathrm{~mm}$ の大型パネルである。リブ付きのアルミニウム合金 押出形材を FSWにより幅方向に並列に接合した広幅材は, 各分野でうまく利用されており，非溶融溶接である FSW は 2000 系や 7000 系合金にも適用が可能で, 航空機においては リベットを使わない線接合が可能になるので軽量化や製造コ ストの点で意義は大きい。 


\section{5. おわりに}

日本の 20 世紀における航空機用アルミニウム合金開発の 歴史を述べてきたが，超々ジュラルミンやテーパストリンガ に見られるように，アルミニウムメーカーは，戦前は海軍の 要求に, 戦後は機体メーカーのニーズに応える材料開発を 行ってきた。

超々ジュラルミンやテーパストリンガは海外ではできない 日本オリジナルな発明である。戦後は航空機用アルミニウム 合金開発においては，航空機生産がボーイングのTier 1 とし て胴体の分担生産を行うことになり，アルコアの特許合金を ボーイングが認定していく構図となったため, 日本において 航空機用新合金開発はほとんど行われなくなった。今後，機 体メーカーや部品メーカーは国産の航空機を開発するにあた り, もっと材料メーカーに要望を出せばきっとそれに応える 新材料を開発するであろう。材料メーカーも将来の航空機の 発展を考えて長期的な展望に立って国産の航空機材料を開発 すればそれは大きな果実となるであろう。機体メーカー, 部 品メーカー，素材メーカーがもっとしっかりと手を結んで開 発していくことが世界での競争に打ち勝つことになるものと 考えている。

\section{参 考 文 献}

1）吉田英雄：住友軽金属技報，53（2012），60-78

2）吉田英雄：住友軽金属技報，54（2013），264-326.

3) 竹内勝治：アルミニウム合金展伸材一その誕生から半世紀一, 軽金属溶接構造協会, (1986).

4) 竹内勝治：技術の歩み, 住友軽金属工業株式会社, (1995), （非 売品).

5) 住友軽金属年表（平成元年版，住友軽金属工業株式会 社, (1989).

6) J. Christopher: The Zeppelin Story, The History Press, (2010), 78.

7) P. W. Brooks: Zeppelin Rigid Airships, 1893-1940, Smithsonian Institution Press, (1992), 176

8) 牧野光雄：飛行船の歴史と技術, 成山堂書店, (2010).

9) http://www.ne.jp/asahi/airplane/museum/nakajima/nakajima.html

10) http://www.louisvilleartdeco.com

11）日本の航空宇宙工業（平成26年度版），一般社団法人日本航空 宇宙工業会, (2014)

12）民間航空機関連デー夕集（平成 26 年度版），一般財団法人日本 航空機開発協会, (2015). Wikipediaなど参照.

13）横倉 潤：翔べ! YS-11, 小学館, (2004).

14) YS-11物語, エアライナークラブ編，JTBパブリッシン グ, (2006).

15) http://nekocraft.blog.so-net.ne.jp/2012-12-14-1

16) http://ja.wikipedia.org/wiki/ファイル : Mits. MU-2.JPG

17) http://ja.wikipedia.org/wiki/ファイル : N417KTatBNA.JPG

18) https://www.jal.co.jp/aircraft/

19）馬場義雄：住友軽金属技報，29（1988），29-46，31（1990）, 65-81, 41 (2000), 91-121.
20) T. Uno, H. Yoshida and Y. Baba: Aluminum Alloys; Their Physical and Mechanical Properties (ICAA-1), Vol. 1. ed. by E. A. Stark, Jr. and T. H. Sanders, Jr., EMAS, (1986), 371-385.

21）住友軽金属技報：新製品紹介, 航空機ストリンガー用微細結晶 粒 7075 合金板, 23 (1982)， 120.

22) 日本航空宇宙工業会 : 航空機部品・素材産業振興に関する研究 調査, 低コスト胴体構造部品加工法の開発, 三菱重工業, 住友 軽金属工業, 成果報告書, No. 807（1994）, No. 904（1995）。

23）箕田 正, 吉田英雄, 都筑隆之：軽金属，49（1999）, 161-165.

24) 広田和弘, 佐藤正五, 伊原木幹成, 木村隆嗣, 中村康一: 三菱 重工技報，33（1996），158-161.

25）日本航空宇宙工業会，革新航空機技術開発センター：革新航空 機技術開発に関する研究調査，超塑性高力アルミニウム合金の 開発および一体化加工法の研究, 住友軽金属工業, 三菱重工業, No.802(1984), No.901(1985), No.6001 (1986) .

26) 日本航空宇宙工業会：航空機部品・素材産業振興に関する研究 調査, Al-Li合金の超塑性材料開発, 超塑性加工法の研究, 三 菱重工業, 住友軽金属工業, 成果報告書, No. 105（1987）, No. 205 (1988), No. 307 (1989).

27）高橋明男，都筑隆之：軽金属，39（1989），224-234。

28) 江藤武比古：軽金属, 49 (1999), 332-335.

29）吉田英雄：住友軽金属技報，37（1996），90-98.

30）吉田英雄, 田中宏樹, 土田 信: 軽金属, 39（1989）, 817-823.

31）吉田英雄：住友軽金属技報，36（1995），37-46.

32）都筑隆之, 高橋明男：軽金属, 39（1989），824-830.

33) http://blog.goo.ne.jp/boeing767_fan/e/ebcb9807f00eb82400d40ef 80474a987

34) 日本航空宇宙工業会：航空技術水準の向上に関する研究調査, 航空機用広幅長尺高力アルミ合金板製造技術の研究，神戸製鋼 所, No.19 (1980).

35）木村隆嗣, 高橋孝幸, 大西哲也, 江藤武比古, 中井 学: 三菱 重工技報，35（1998），326-329.

36) 堀内健文, 川手剛雄, 上坂辰男, 福塚敏夫, 西本英敏 : 神戸製 鋼技報，32-2（1982），40.

37）立松武雄, 高田与男, 黑崎敏夫：神戸製鋼技報，31-1（1981）, 24.

38） Furukawa-Sky Review，新技術紹介，No. 1 (2005)， 52.

39) 日本航空宇宙工業会: 革新航空機技術開発に関する研究調査, 高勒性アルミニウム合金の開発の研究, 神戸製鋼所, 住友軽金 属工業, 古河アルミニウム工業, 成果報告書, No. 506 (1981), No. 603 (1982), No.702 (1983)

40）軽金属学会研究委員会: 高強度 $\cdot$ 高鞄性アルミニウム合金の諸 性質, 研究部会報告書 No. 13, (1985)

41) 軽金属学会研究委員会: Al-Li合金, 研究部会報告書 No. 21, (1989).

42) 金属系材料研究開発センター, アルミニウム系新材料の高機能 化に関する調査部会：高比強度アルミニウム合金調査WGの調 査研究報告書, (1998)，（1999），（2000）。

43）吉田英雄，内田秀俊：住友軽金属技報，34（1993），87-98.

44) 航空機国際共同開発促進基金【解説概要 24-2】, 航空機用アル ミリチウム合金扔よび航空機産業の最近の動向 http://www. iadf.or.jp/8361/LIBRARY/MEDIA/H24 dokojyoho/24-2.pdf

45) 日本航空宇宙工業会: 先端航空機部品・素材技術に関する研究 調査，摩擦攪拌接合を用いたアルミ合金製大型押出部材の航空 機への適用化研究, 三菱重工業, 住友軽金属工業, 成果報告書, No. 1405 (2000), No. 1502 (2001) 